\title{
Embryonal Carcinoma with Immature Teratoma: A Homeopathic Case Report
}

\author{
Seema Mahesh $^{a}$ Mahesh Mallappa $^{a}$ George Vithoulkas $^{b}$ \\ ${ }^{a}$ Centre for Classical Homeopathy, Vijayanagar, Bangalore, India; \\ b University of the Aegean, International Academy of Classical Homeopathy, Alonissos, Northern Sporades, Greece
}

\section{Keywords}

Embryonal carcinoma - Immature teratoma .

Homeopathic management of cancer

\section{Summary}

Background: Embryonal carcinoma with immature teratoma is a cancer with poor prognosis if the expression levels of biological markers are very high. In such a case, after surgical removal of the tumor, homeopathic treatment resulted in maintenance of the cancer-free state for over 6 years. Case Report: This is the case of a 3-year-old Indian girl diagnosed with embryonal carcinoma with immature teratoma (after surgery), treated and followed up for over 6 years. She was treated on the basis of the principles of classical homeopathy and has stayed free of cancer for 6 years now. Discussion: The cancer marker expression levels dropped while the girl developed severe skin eruptions, which is in accordance with the laws of classical homeopathic treatment. Although other examples of successful homeopathic treatment in severe pathologies exist, further confirmatory studies are needed on a large scale.

(c) 2017 The Author(s). Published by S. Karger GmbH, Freiburg

\section{Introduction}

Germ cell tumors consist of primitive cell types in different stages of differentiation. Embryonal carcinoma (EC) consists of poorly differentiated cells [1] with a tendency to spread fast. When coupled with other benign types (e.g. mature teratoma), mutation

\section{Schlüsselwörter}

Embryonales Karzinom - Unreifes Teratom . Homöopathische Krebsbehandlung

\section{Zusammenfassung}

Hintergrund: Ein embryonales Karzinom mit einem unreifen Teratom ist eine Krebsart mit einer schlechten Prognose, wenn sehr hohe Expressionslevel der biologischen Marker vorliegen. In solch einem Fall führte eine homöopathische Behandlung nach der chirurgischen Entfernung des Tumors zur Aufrechterhaltung des krebsfreien Zustands für mehr als 6 Jahre. Fallbericht: Dies ist der Fall eines 3-jährigen indischen Mädchens, das (nach Operation) die Diagnose eines embryonalen Karzinoms mit einem unreifen Teratom erhielt und das mehr als 6 Jahre lang behandelt und nachbeobachtet wurde. Sie wurde gemäß den Prinzipien der klassischen Homöopathie behandelt und ist jetzt seit 6 Jahren frei von Krebs geblieben. Diskussion: Die Expressionslevel der Krebsmarker fielen, während das Mädchen schwere Hautausschläge entwickelte, was mit den Gesetzen der klassischen homöopathischen Behandlung in Einklang steht. Obwohl es noch andere Beispiele für eine erfolgreiche homöopathische Behandlung bei schwerwiegenden $\mathrm{Pa}$ thologien gibt, sind weitere, groß angelegte Studien, die dies untermauern, notwendig.

into malignancy is regularly found [2]. Immature teratoma is rare among germ cell tumors and has the tendency to spread aggressively [3]. ECs exhibit a predominantly maternal genetic imprinting $[4,5]$ and recurrence is as high as $33 \%$ after surgery and chemotherapy [6]. Germ cell tumors secrete biological markers that serve to monitor the treatment results and to detect subclinical re- 
Table 1. Evolution of the case after the first remedy

\begin{tabular}{|c|c|c|c|}
\hline Date & Symptoms & Prescription & Remarks \\
\hline 08/09/2009 & $\begin{array}{l}\text { AFP: } 3.57 \mathrm{mg} / \mathrm{ml}(\text { normal: }<10) \text {; } \\
\text { HCG: }<2.0 \mathrm{mIU} / \mathrm{ml}(\text { normal: }<1 \text { ); } \\
\text { ESR: } 12 \mathrm{~mm} / \mathrm{h}\end{array}$ & $\begin{array}{l}\text { Tuberculinum 14C } \\
\text { continued }\end{array}$ & $\begin{array}{l}\text { obvious good result as the cancer } \\
\text { markers remain low; therefore, } \\
\text { no change in remedy was required }\end{array}$ \\
\hline $12 / 09 / 2009$ & $\begin{array}{l}\text { relapse of cold and cough, } \\
\text { persisting for } 1 \text { week now }\end{array}$ & $\begin{array}{l}\text { Tuberculinum } 16 \mathrm{C} \\
1 \text { dose a day for } 1 \text { month }\end{array}$ & $\begin{array}{l}\text { onset of an acute inflammation; } \\
\text { therefore, the potency was increased }\end{array}$ \\
\hline $29 / 10 / 2009$ & $\begin{array}{l}\text { tonsils enlarged on both sides, } \\
\text { cough persists }\end{array}$ & $\begin{array}{l}\text { Tuberculinum } 18 \mathrm{C} \\
1 \text { dose a day for } 1 \text { month }\end{array}$ & $\begin{array}{l}\text { the acute inflammation gets stronger; } \\
\text { thus, the potency was further increased }\end{array}$ \\
\hline $12 / 11 / 2009$ & $\begin{array}{l}\text { AFP: } 2.5 \mathrm{mg} / \mathrm{ml} \text {; } \\
\text { HCG: }<2.0 \mathrm{mIU} / \mathrm{ml} \text {; } \\
\text { ESR: } 6 \mathrm{~mm} / \mathrm{h}\end{array}$ & & \\
\hline $23 / 11 / 2009$ & fever and cough relapsed & $\begin{array}{l}\text { increased dosage to } \\
3 \text { times a day }\end{array}$ & $\begin{array}{l}\text { the number of doses was increased as a } \\
\text { potency change was not indicated }\end{array}$ \\
\hline $15 / 12 / 2009$ & cough persisting & $\begin{array}{l}\text { Tuberculinum 20C } \\
1 \text { dose a day for } 1 \text { month }\end{array}$ & $\begin{array}{l}\text { the acute condition was progressing and } \\
\text { therefore the potency was increased }\end{array}$ \\
\hline $22 / 01 / 2010$ & $\begin{array}{l}\text { rattling in the chest during sleep; } \\
\text { occasional pain in the abdomen } \\
\text { > stools }\end{array}$ & $\begin{array}{l}\text { Tuberculinum } 22 \mathrm{C} \\
1 \text { dose a day for } 1 \text { month }\end{array}$ & \\
\hline $18 / 02 / 2010$ & no acute conditions since 1 month & $\begin{array}{l}\text { Tuberculinum } 24 \mathrm{C} \\
1 \text { dose a day for } 1 \text { month }\end{array}$ & $\begin{array}{l}\text { in a chronic case, when the case is in } \\
\text { status quo, a potency increase after a } \\
\text { certain period allows for further progress }\end{array}$ \\
\hline
\end{tabular}

Table 2. Repertorization during skin eruptions

\begin{tabular}{lll}
\hline Sl. no. & Symptom & Qualification \\
\hline 1 & face - eruptions - crusty, scabby - around mouth & 1 \\
2 & generals - touch - egg - in children & 1 \\
3 & generals - touch - egg - slight & 2 \\
4 & generals - touching - anything - egg & 2 \\
5 & generals - lying - on back - unable to turn from back & 1 \\
6 & sleep - position - on back & 2 \\
7 & sleep - position - on back - feet drawn up & 2 \\
8 & mind - complaining - pitiful - in children & 2 \\
9 & generals - uncovering - desire for & 2 \\
\hline Sl. no. = serial number. & \\
\hline
\end{tabular}

currences [3]. ECs exhibit high levels of human chorionic gonadotropin (HCG) in the blood and also $a$-fetoprotein (AFP). The presence of high levels of AFP and a bigger size of the tumor in the case of a germ cell tumor herald a very bad prognosis. Even with the latest, better prognosis reports, the initial surgery needs to be followed up with adjuvant chemotherapy to ensure complete clearance of the cancerous cells $[3,7]$.

\section{Case Report}

A 3-year-old girl child with EC and immature teratoma underwent surgical removal of the tumor in the ovary, after which the family, when given chemotherapy as the next option of treatment, refused and opted for homeopathic treatment.

The initial anamnesis of the case took place on August 13, 2009.

The mother had detected a large swelling in the abdomen of the child, which was revealed on the ultrasound scan to be a large ovarian tumor of suspected ovarian neoplasm, measuring $7.1 \times 1.3 \times 2.4 \mathrm{~cm}$ (dated June 22, 2009).
This tumor was excised and biopsied. The biopsy showed a malignant mixed-germ cell tumor consisting of immature teratoma and EC (70\% and 5\%, respectively) (dated July 29, 2009).

The laboratory findings, dated July 23, 2009, prior to removal of the tumor were:

- hemoglobin (Hb): $9.7 \mathrm{~g} \%$

- erythrocyte sedimentation rate (ESR): $38 \mathrm{~mm} / \mathrm{h}$

- total HCG: $956.3 \mathrm{mIU} / \mathrm{ml}$ (normal: $<1 \mathrm{mIU} / \mathrm{ml}$ )

- AFP: $1,336 \mathrm{mg} / \mathrm{ml}$ (normal: $<10 \mathrm{mg} / \mathrm{ml}$ )

- lactose dehydrogenase (LDH): $281 \mathrm{U} / 1$ (normal)

Past history: She suffered from recurrent colds and adenoids.

Family history: On the father's side of the family there were many genetic disorders and congenital disorders.

The mother reported that she had had tremendous stress during the pregnancy as she had to separate from her husband during that time, which ultimately ended in divorce. Further, the mother has recently been diagnosed with breast cancer (in 2015).

Presenting symptoms available for homeopathic repertorization were: The girl ground her teeth in her sleep, she had increased perspiration during sleep, and her tongue was furrowed in the center; her thirst was very much decreased. She craved cold milk and bananas and had an aversion to eggs. 


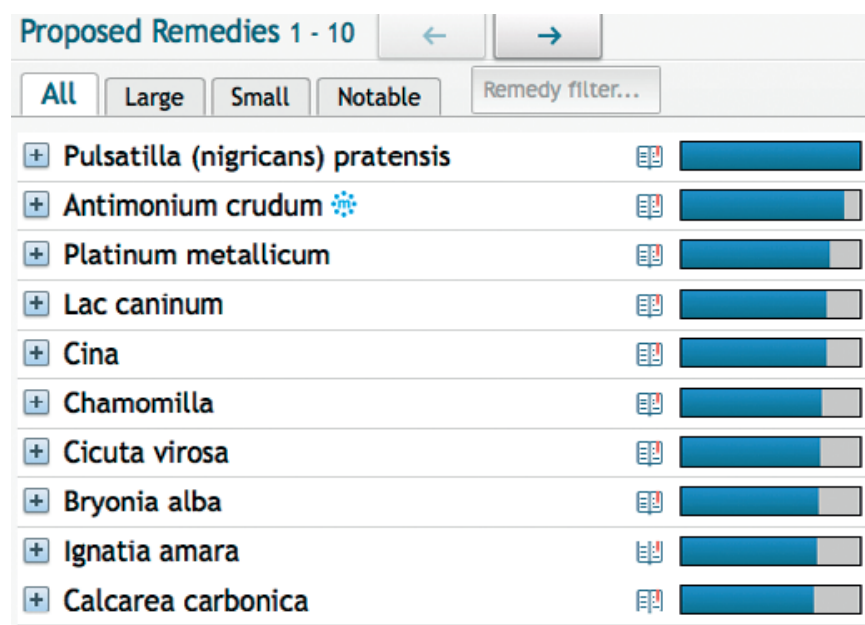

Fig. 1. Repertorization results during skin eruptions.
Fig. 2. Progression of the skin eruptions from the face down to the body (fig. 2-4).

Fig. 3. Progression of the skin eruptions from the face down to the body (fig. 2-4).

Fig. 4. Progression of the skin eruptions from the face down to the body (fig. 2-4).
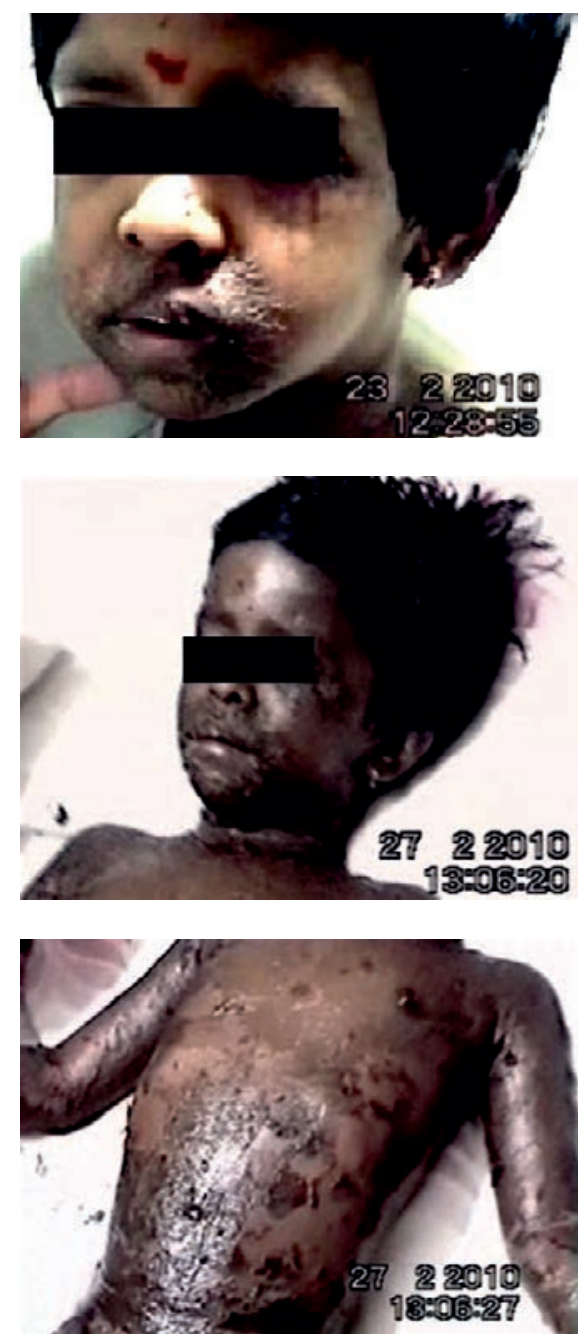

In the homeopathic Materia Medica, these symptoms very clearly constitute the picture of a single remedy [8].

The assessment regarding her health was that, although she had the diagnosis of cancer and her cancer marker levels were very high to begin with, she exhibited frequent acute infections and the immune system was strong enough to

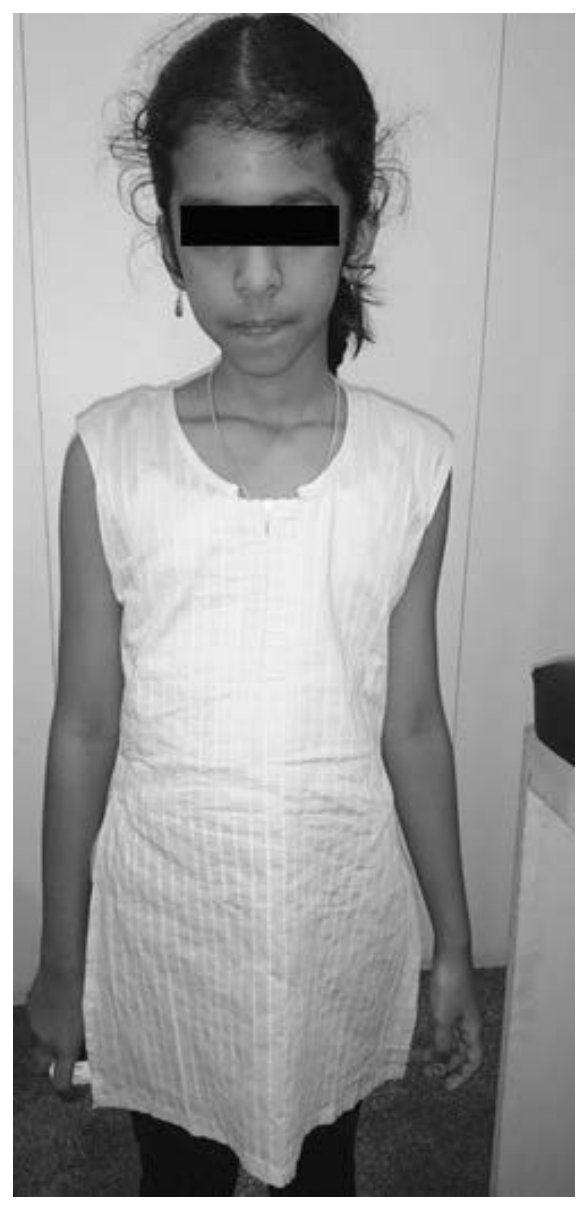

Fig. 5. Latest pictur of the girl.

put up a clear picture of a homeopathic remedy, implying that she was on a better level [9].

At this level, the prescription strategy is based on the totality of symptoms, which includes the sum of all the individualistic symptoms of the patient. Vithoulkas' [10] expert system of the radar software was used for repertorization.

The remedy given was Tuberculinum 14C, 1 dose per day for 1 month. Follow-up consultations of the first part of the treatment are listed in table 1.

The girl received only homeopathic treatment.

During 5 months of treatment with Tuberculinum in rising $\mathrm{C}$ potencies, the child underwent several acute infections of the upper respiratory tract, which stopped when she developed skin eruptions around the mouth. The eruptions were cracked, crusty, and painful.

Placebo 3 times a day for 5 days was prescribed, as we saw a stable situation in cancer markers. The beginning of a skin eruption in cases with deep affections is always a good sign according to the theory and the idea of a hierarchical organization of the human organism $[9,11]$. One day later, though, the eruptions took a dangerous shape and were threatening to spread. Thus, they needed to be treated. The symptoms on February 24, 2010, considered for repertorization were as given in table 2 .

The repertorization showed Pulsatilla as the remedy (fig. 1): Pulsatilla 30C was given.

Follow-up of the skin treatment and its process are summarized in table 3 and in figures $2-4$.

The child has now been observed for 6 years, with periodical scans and blood tests as surveillance for relapse of cancer. There has been no evidence, so far, of any cancerous activity in the body, and the girl has stayed well.

She required occasional treatment for acute infections, which over time have become rarer.

The reports of the 6 years are given in table 4 . The latest photograph of the girl is provided as figure 5 . 
Table 3. Evolution of the case after the second remedy

\begin{tabular}{|c|c|c|c|}
\hline Date & Symptoms & Prescription & Remarks \\
\hline $25 / 02 / 2010$ & $\begin{array}{l}\text { immediately after application of the remedy, the } \\
\text { swelling of the eyelid and mouth became less; the } \\
\text { child could open the mouth; the dangerous areas } \\
\text { are clearing up while the lower parts are becoming } \\
\text { affected }\end{array}$ & $\begin{array}{l}\text { Pulsatilla } 30 \mathrm{C} \\
2 \text { doses a day }\end{array}$ & $\begin{array}{l}\text { clearly the case is better (downward movement } \\
\text { of the lesions as they clear up from above), } \\
\text { but it is still severe, thus needing repetition }\end{array}$ \\
\hline $26 / 02 / 2010$ & $\begin{array}{l}\text { skin lesions shifting to neck and downwards; } \\
\text { itching all over the body, more in the genital area; } \\
\text { fever of } 101.8 \mathrm{~F} \text {; appetite improved; asks for food; } \\
\text { thirst for } 1 \frac{1}{2} \text { a glass in a day; sleepless; no stools } \\
\text { since last day }\end{array}$ & $\begin{array}{l}\text { Pulsatilla 200C, } \\
\text { every } 4 \mathrm{~h}\end{array}$ & $\begin{array}{l}\text { fever onset indicates active immune system, } \\
\text { but care needs to be taken as the skin lesions are } \\
\text { extensive and chances of septicemia must be } \\
\text { ruled out; this state requires frequent repetition } \\
\text { to assist in recovery }\end{array}$ \\
\hline $27 / 02 / 2010$ & $\begin{array}{l}\text { temperature } 100.2 \mathrm{~F} \text {; skin peeling on abdomen and } \\
\text { back; appetite good; asks for oranges }\end{array}$ & $\begin{array}{l}\text { Pulastilla 200C } \\
3 \text { doses a day }\end{array}$ & $\begin{array}{l}\text { reduced fever and healing skin: very good } \\
\text { development, so dosage reduced }\end{array}$ \\
\hline $28 / 02 / 2010$ & $\begin{array}{l}\text { shivering and startling observed in the child; food } \\
\text { intake a little reduced; thirst remains the same; she } \\
\text { asks for fruits; skin peeled on genitals; she cries } \\
\text { while passing stools }\end{array}$ & $\begin{array}{l}\text { Pulsatilla } 200 \mathrm{C} \text { only } \\
\text { if fever rises }\end{array}$ & $\begin{array}{l}\text { at this stage, we must observe if the immune } \\
\text { system can take care of itself, by observing fever; } \\
\text { therefore, remedy repeated only if required }\end{array}$ \\
\hline 02/03/2010 & $\begin{array}{l}\text { sleep was good; normal skin appearing in some } \\
\text { parts; lesions descended to feet; fever had risen to } \\
102 \text { F in the night (upon giving the Pulsatilla dose); } \\
\text { now temperature } 98 \mathrm{~F} \text {; reddish gums; stools still } \\
\text { hard; trembling when standing }\end{array}$ & placebo & remedy repeated only when required \\
\hline 04/03/2010 & new skin appearing further & placebo & $\begin{array}{l}\text { healing skin and better immune status warrants } \\
\text { no remedy }\end{array}$ \\
\hline 06/03/2010 & $\begin{array}{l}\text { skin peeling off gradually and new skin appearing; } \\
\text { swelling in right eye; generally well }\end{array}$ & placebo & \\
\hline 08/03/2010 & skin peeling better; generally better & placebo & \\
\hline $13 / 03 / 2010$ & $\begin{array}{l}\text { drastic changes in the whole body; scar marks are } \\
\text { disappearing as well; appetite improved }\end{array}$ & placebo & \\
\hline $19 / 03 / 2010$ & swelling of tonsils; mild cough & $\begin{array}{l}\text { Pulsatilla } 200 \mathrm{C} \\
2 \text { doses a day for } 2 \text { days }\end{array}$ & $\begin{array}{l}\text { now the child is out of danger and is showing } \\
\text { signs of a common cold; as a rule, the previous } \\
\text { remedy must be repeated }\end{array}$ \\
\hline 27/03/2010 & swelling better; mild cough & $\begin{array}{l}\text { Pulsatilla 200C } 2 \text { doses } \\
\text { per day for } 3 \text { days }\end{array}$ & \\
\hline $10 / 04 / 2010$ & skin is better; tonsils are still swollen & $\begin{array}{l}\text { Pulsatilla } 200 \mathrm{C} 2 \text { doses } \\
\text { a day for } 10 \text { days }\end{array}$ & \\
\hline $25 / 04 / 2010$ & $\begin{array}{l}\text { generally well; occasionally complains of pain in } \\
\text { abdomen }\end{array}$ & placebo & $\begin{array}{l}\text { from here on, the case was treated as and when } \\
\text { required for the onset of common colds alone }\end{array}$ \\
\hline
\end{tabular}

Table 4. Imagery and blood tests follow-up after homeopathic treatment

\begin{tabular}{ll}
\hline Date & Report \\
\hline $06 / 02 / 2012$ & CT scan shows bilateral lymphadenopathy, but otherwise normal condition \\
$11 / 02 / 2012$ & AFP: $1.78 \mathrm{mIU} / \mathrm{ml}$ \\
$01 / 04 / 2013$ & CT scan shows normal condition; AFP: $1.03 \mathrm{mIU} / \mathrm{ml}$ \\
$26 / 07 / 2014$ & ultrasound scan shows normal condition \\
$28 / 07 / 2015$ & ultrasound scan shows normal condition \\
\hline CT = Computed tomography, AFP $=\alpha$-fetoprotein. \\
\hline
\end{tabular}

\section{Discussion}

Although it may be difficult to achieve such a response in all cases with such a poor prognosis, this case report still demonstrates the potential that homeopathy has as a treatment modality for serious pathologies. There have been other case reports where the pathological state was very advanced and yet homeopathic treat- ment was successful [12]. This is probably because the patients, despite their advanced pathologies, were still in a better condition of health. In such cases, homeopathic medicines can elicit favorable reactions from the immune system $[9,11]$. The follow-up has lasted for over 6 years, during which time the dramatic skin eruptions also responded well to homeopathy, leaving the girl in an overall healthier state. 


\section{Conclusion}

This case report, as far as the authors' knowledge goes, is the first of its kind where a severe pathology has been shown to respond and stay clear for over 6 years. The dramatic nature of the case and the response to treatment make it necessary to further investigate the possibilities of homeopathic treatment in such severe pathological conditions.

\section{Author's Contributions}

S.M. wrote the manuscript, M.M. was the homeopathic physician who treated the case and contributed the complete details of analysis and prescription. G.V. was the guide under whose directions and ideas the manuscript was prepared. All authors have read and approved the final manuscript.

\section{Disclosure Statement}

The authors declare that there is no conflict of interest concerning this paper.

\section{References}

1 Cotran R, Kumar V, Collins T: Robbins Pathologic Basis of Disease, ed 6. Philadelphia, W.B. Saunders, 1998, pp 1018-1024, 1073-1075.

2 Bass P: Germ Cell Tumors. Online Medical Encyclopedia. Rochester, University of Rochester Medical Center 2017.

3 Rana S, Kaur Gill M, Satarkar R, Sangwaiya A, Singh P: Immature teratoma with embryonal carcinoma; a rare malignant mixed germ cell tumor in a 13-year-old girl. Iran J Pathol 2016;11:66-70.

4 Mutter G: Role of imprinting in abnormal human development. Mutat Res 1997;396:141-147.

5 Jirtle R: Genomic imprinting and cancer. Exp Cell Res 1999;248:18-24.
6 Pediatric teratomas and other germ cell tumors: background, pathophysiology, etiology. http://emedicine. medscape.com/article/939938-overview, 2017 (last accessed September 13, 2017).

7 Khaleghnejad-Tabari A, Mirshemirani A, Rouzrokh M, Mohajerzadeh L, Khaleghnejad-Tabari N, HasasYeganeh S: Pediatric germ cell tumors; a 10-year experience. Iran J Pedatr 2014;24:441-444.

8 Online Materia Medica, International Academy of Classical Homeopathy, https://www.vithoulkas.com/ learning-tools/online-materia-medica/search?remedy = Tuberculinum\%20bovinumemedica = 0\&search = ఓtype = 1, 2017 (last accessed September 13, 2017).
9 Vithoulkas G: Levels of Health. Alonissos, International Academy of Classical Homeopathy, 2017.

10 Vithoulkas Expert System. Lago Maggiore, Radar Synthesis, 1989

11 Vithoulkas G, Tiller W: The Science of Homeopathy. Athens, International Academy of Classical Homeopathy, 2009, pp 23-52.

12 Mahesh S, Mallappa M, Vithoulkas G: Gangrene: five case studies of gangrene, preventing amputation through homoeopathic therapy. Indian J Res Homoeopath 2015;9:114. 